\title{
DOE/RA/50102--T6
}

\section{DE82 007215}

DISCLAIMER

This book was prepared as an account of work sponsored by an wency of tha United States Government. Neither the United States. Governmont nor any mency thereot. nor any of their emplowees; makes any completeness. or ur implied, of assumes myy legal liability or responsiblity for the cocuracy. represents that its use would not infringe priventy opparatus, product. Of procass disclosed, of

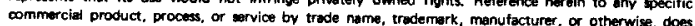

not necossarily constitute or imply its endorsement. recommendation, or teroring by the Unitod

States Government or any agency thereot. The vieust and opinions of authors expresed nerein do not

nocesserily state or reflect those of the United States Government or any menchy thereof.

DOE|RA|50102--T6

ALTERNATIVE INSTITUTIONAL VEHICLES

FOR

GEOTHERMAL DISTRICT HEATING

\author{
Sandra Bressler \\ Thomas C. Gardner \\ Diana King \\ John T. Nimons
}

June 1980

\section{GEOTHERMAL COMMERCIALIZATION PROJECT}

THE EARL WARREN LEGAL INSTITUTE

UNIVERSITY OF CALIFORNIA

BERKELEY, CALIFORNIA 
DISCLAIMER

This report was prepared as an account of work sponsored by an agency of the United States Government. Neither the United States Government nor any agency Thereof, nor any of their employees, makes any warranty, express or implied, or assumes any legal liability or responsibility for the accuracy, completeness, or usefulness of any information, apparatus, product, or process disclosed, or represents that its use would not infringe privately owned rights. Reference herein to any specific commercial product, process, or service by trade name, trademark, manufacturer, or otherwise does not necessarily constitute or imply its endorsement, recommendation, or favoring by the United States Government or any agency thereof. The views and opinions of authors expressed herein do not necessarily state or reflect those of the United States Government or any agency thereof. 


\section{DISCLAIMER}

Portions of this document may be illegible in electronic image products. Images are produced from the best available original document. 
This report was prepared under contract No. DE-ACO380RA50102 for the United States Department of Energy. Neither the United States nor any of its employees, contractors, subcontractors, or their employees, makes any warranty, expressed or implied, or assumes any legal liability to third parties for the content hereof. All opinions, findings, conclusions and recommendations expressed in this publication are those of the authors and do not necessarily reflect the views of the Department of Energy. 


\section{TABLE OF CONTENTS}

Page

BACKGROUND AND INTRODUCTION

A. Background ................... 1ii

B. Introduction .................... vi

PART ONE

Legal Characteristics of Alternative Institutions

I. PUBLIC ENTITIES: CITIES, COUNTIES AND SPECIAL DISTRICTS

A. Authority to Undertake Geothermal Activity

1. Source of Authority .............. . 1

a. Citles and Counties ...........

1. General law governments ...... . 2

i1. Home rule governments ....... . 2

b. Speclal Districts ............ 7

2. Existing Authority for Geothermal Systems . . . . 8

a. Type of Services Covered . . . . . . 8

b. Scope of Activities Authorized ........ 13

B. Territorial Issues .............. 18

C. Formation and Management Structure

1. Formation .................... 25

2. Management Structure . . . . . . . . . . 27

D. Public Utility Regulation . . . . . . . . . 29 
II. PRIVATE ENTITIES: COOPERATIVES AND PRIVATELY OWNED COMMERCIAL ENTERPRISES

A. Cooperatives

1. Introduction ............... 32

2. Formation and Attributes of Cooperatives . . . . . 34

a. Cooperative Statutes .......... . 34

b. Nonprofit Statutes........... 37

c. General Incorporation Statutes . . . . . . 40

d. Unincorporated Cooperatives ..... . . . 41

3. Regulation

a. Securities Registration .......... 42

b. Public Utility Regulation .......... 44

4. Taxation

a. Federal Income Tax Treatment ........ 46

b. Other Taxes ............... 49

B. Privately Owned Commercial Enterprises

1. Introduction ................. 50

2. State Public Utility Regulation, in General .... 52

3. Application to Geothermal HeatIng Systems . . . . 53

4. Implications for Geothermal Development . . . . 56 


\section{BACKGROUND AND INTRODUCTION}

\section{A. BACKGROUND}

This interim report is part of a larger effort by the Ear1 Warren Legal Institute to identify and address current institutional, legal and economic barriers to the comercialization of geothermal energy for direct uses.

Earlier DOE-sponsored studies with similar objectives focused on what might be called the first generation of issues in the development of a commercial geothermal industry -- how to clarify the legal status of geothermal resources, how to ensure that geothermal rights are leased in an efficient and timely manner, how to accelerate the permitting process for exploration and development, and how to structure appropriate tax incentives for geothermal activities. Our work over, the past two years has addressed a second generation of policy issues which has emerged as a result of Increased geothermal activity made possible by these earlier DOE efforts. The central question we have been addressing is this: given progress in removing the first generation of Institutional and legal obstacles to geothermal development, will there be a supply of and a demand for geothermal resources, and what institutional factors will promote or 1nhibit widespread utilization of the resource for direct heating applications?

Our work to date has focused largely on the demand side of this question. Our aim has been to Identify the range of alternative 
players which may be involved in a commercial geothermal industry, to define the alternative institutional structures in which they may operate, and to analyze the key features of the resulting decisionmaking process: who are the critical decision-makers, what factors determine their energy choices, and how can government policy most effectively address their concerns and influence these choices?

To answer these questions, we began by interviewing persons Involved in all the major existing direct heating applications in the western states. We then conducted in-depth Interviews with some 60 firms which do not currently employ geothermal resources, but which represent industries targeted by Federal and state energy planners and resource developers as potential users of geothermal heat. As a complement to this work, we designed and conducted a similarly comprehensive survey of existing gas and electric utilities in states known to have geothermal potential. Our objective was to determine their interest in developing and/or distributing geothermal for direct heating applications, the business and regulatory constraints which would affect their decisions in this area, and the types of government measures necessary to encourage their participation.

Responses to our survey of potential user industries reveal that while many firms would welcome the opportunity to utilize geothermal heat if they could obtain it as simply as they now obtain conventional fuels, few of them would consider relocating to take 
advantage of a resource. Even assuming a nearby resource, fewer still would be able or willing to undertake exploration or development activities, or to distribute spent fluids for use by others where this might result in public utility status.* To encourage commercial uses, then, someone else must perform these essential functions in many cases.

Our public utility survey, however, suggests that existing conventional utilities-which are commonly viewed as logical candidates for these tasks--can be expected to play a limited role in this area, at least in the near term. Most major investor-owned utilities doubt that geothermal heating can significantly relieve their demand pressures and believe that high fixed management and overhead costs cannot justify the anticipated small scale of geothermal projects. Publicly owned municipal, district and rural utilities are generally more receptive, but many face institutional, political, and financing uncertainties which need to be defined and resolved if these entities are to become active in geothermal efforts.**

The aversion of many potential users to relocating or to undertaking exploration and development on their own, the limited interest of large investor-owned utilities, and the uncertainties facing publicly owned utilities in this area all point to the need for a broader inquiry Into the range of alternative institutional vehicles available to develop

*For detailed reports on the methodology and results of these Industry surveys, see Bressler, Sandra, et al., "Prospects for Geothermal Commerclalization in the Chemical Industry," "Prospects for Geothermal Commercialization in the Lumber Industry," "Prospects for Geothermal Commerclalization in the Potato and Onion Industry," and "Prospects for Geothermal Commercialization in the Greenhouse Industry" (Earl Warren Legal Institute, March 1980).

** See King, Diana, et al., "The Role of Gas and Electric Utilities in Direct Applications of Geothermal Resources" (Ear1 Warren Legal Institute, March 1980). 
and distribute the resource to industrial, commercial and residential customers who could benefit from its use.

Part I of this report Identifies institutional vehicles suited to undertake these functions in varying settings; reviews the powers, authority and manner of operation of each of them; and considers some of the public utility regulatory implications which may affect choices among available alternatives. Part 2 examines financing considerations for the various entities and their advantages and disadvantages for particular types of geothermal heating applications.

\section{B. INTRODUCTION}

Resource characteristics and system economics dictate that geothermal heating systems will be essentially local operations, governed by relatively site-spectfic considerations. Their local character suggests that the inquiry should focus on institutional models which perform similar utility functions within a limited geographical area. Their site-specificity implies that institutional mechanisms appropriate for one type of application in a particular geographical or polftical setting may not be suited to differing applications in other settings, and that no single institutional vehicle will be ideal for all cases. 
The range of functions to be performed by a local geothermal entity may vary depending upon the institutional vehicle or combination of vehicles chosen, and may include functions not ordinarily undertaken by similar local entities. Geothermal exploitation will typically involve the acquisition of surface and resource rights, basic exploration activities, field development and fluid production and, in the applications with which we are concerned here, construction and operation of distribution facilities, marketing and customer service. Not all of these functions will be required in every application; In some cases, for example, the developing entity may already own the land and the resource rights, or an existing well may obviate exploration requirements. Moreover, all of these functions need not be performed by the same Institutional entity; often, for example, an independent resource company may undertake exploration and field development, and thereafter sell any heat energy produced to a separate entity for distribution.

From an institutional standpoint, dispersed geothermal heating projects will differ from traditional utility projects to the extent that they are perceived to involve high front-end exploration risks and long-term reservoir depletion risks. Traditional local utility services also involve risks: water sources can run dry, and fuels to power turbines or heat buildings can become scarce and costly. Geothermal risks may or may not be higher, but they are clearly newer and less well understood from experience. If they materialize, 
the cost consequences to a particular developer or operator may be greater, and delivery of substitute energy forms to existing consumers may be more difficult. In any case, mechanisms for allocating geothermal risks have not yet been developed or proven in the context of dispersed heating applications.

For these reasons, existing institutional models generally are better prepared to deal with operation and distribution functions than with exploration and reservoir risks. The problem may be less significant or more tractable depending on the type of application and the potential participants. An Industrial park or a shopping center developed by private commercial interests with private capital will have more flexibility than a downtown or residential heating district developed by a public entity; single-purpose special districts will often be more adaptable to novel functions than general-purpose citles and counties. And, as noted above, risk functions may be institutionally segregated from more conventional service activities and their costs allocated by prior arrangement to ensure predictablilty for non-risk orlented enterprises.

In examining avallable Institutional alternatives for geothermal heating, the following discussion proceeds from the premise that the distribution and operation phases of a geothermal enterprise will bear much in common with traditional utility functions and can be accomodated relatively easily by existing institutional mechanisms designed to perform these functions in more conventional 
utility settings. On the other hand, geothermal exploration and development activities, territorial considerations and reservoir depletion risks present novel issues without counterpart in most traditional utility operations. Since the adaptability of existing institutions to geothermal pursuits will turn largely on the resolution of these issues, the discussion focuses on institutional attributes relevant to these subjects.

Succeeding portions of this paper will describe the attributes of various institutional entities which might participate in various phases of geothermal heating applications. Public entities considered include cities, counties and special districts. Private entities discussed include cooperative organizations and non-member-owned private enterprises. 


\section{PART ONE}

\section{LEGAL CHARACTERISTICS OF ALTERNATIVE INSTITUTIONS}




\section{PUBLIC ENTITIES: CITIES, COUNTIES AND SPECIAL DISTRICTS}

A. Authority to Undertake Geothermal Activity

\section{SOURCE OF AUTHORITY}

Cities, counties and districts are governmental units and subdivisions of the state. Cities and counties are general purpose governments; districts are limited governments created to serve a single purpose or a limited number of purposes.

In examining their capacity to undertake geothermal activities, the general rule is that these entities possess no inherent powers, but can act only where the legislature has specifically authorized them to do so under the state's general law. However, an important qualification to this rule applies in more than half of the states, which have constitutional provisions granting some form of "home rule" to at least some of their cities, and in some cases to certain counties as well. As discussed more fully below, home rule Implies that in matters of local as opposed to statewide concern, the city or county has plenary power and may inftiate actions withIn broad limits set by constitutional or statutory home rule provisions, without the need for express statutory authorization for particular activities. (Home rule provisions do not apply to districts, which are strictly limited to the authority granted by their enabling legislation.) 


\section{a. CITIES AND COUNTIES}

i. General law governments. General law cities and counties are governed by the general rule denying inherent powers. Absent statutory or constitutional authorization, a general law government may not undertake any phase of geothermal activity. Authority need not always be framed directly in terms of geothermal energy or the specific activities useful in developing a geothermal system, but should clearly be broad enough to include these. Under the rules traditionally applied to local governments, grants of authority are construed narrowly; only those powers expressly granted and some incidental powers indispenstubte for the exerdse of those expressly granted

will be reoognized. Even where express authority for some geothermal activity has been granted, general law governments must usually find separate statutory authority for the important auxiliary powers necessary for implementing a geothermal system, such as the power to finance and to acquire needed property by condemnation, and often the power to own property and construct facilities and to serve customers outside of their boundaries as well.

11. Home rule governments. Unlike general law governments, home rule cities and counties have some degree of power to exercise local self-government and to take initlative in local matters without the need for statutory authorization. The scope of the home rule power varies widely among the more than thirty states 
with home rule provisions. Some states confer home rule directly by constitutional provision. 1 In others, the constitution directs or authorizes the legislature to establish home rule. ${ }^{2}$

In general, home rule governments can be classified into one of two categories, according to the power conferred by state constitutions or statutes:

(a) Those cities and counties whose plenary power to act in local matters is limited only by the state constitution and their charters. In states with this type of provision ${ }^{3}$ home rule units are not bound by legislative enactments relating to matters of local concern.

(b) Those clties and counties whose power to act in local matters is subject not only to constitutional and charter limitations, but also to the "general law." In states with this type of provision, the general statutory law enacted by the legislature is applicable to home rule units as well as other cities and counties. The home rule power is a residual power to regulate or undertake actions "not prohibited by" 4 or "not inconsistent with"5 the general law.

IE.g., N.M. Const. Art. 10,\$6.

2E.g., Nev. Const. Art. 8, $\$ 8$.

${ }^{3}$ E.g., Cal . Const. Art. XI, \$5; Colo. Const. Art. XX, \$\$1-6.

4E.g., Alaska Const. Art. 10, 111; N.M. Const. Art. X, $\$ 6$.

5E.g., Idaho Const. Art. 12, \$2; Texas Const. Art. XI, \$5. 
Constitutional home rule provisions often enumerate specific powers as within the area of local control. Colorado, for example, provides that home rule cities shall have the power to construct and operate utility systems, including heating systems. 6 However, constitutional provisions may also place limits on the power of home rule. Most importantly for geothermal development, these provisions sometimes restrict home rule powers over municipal finance, includIng taxation and borrowing, and leave home rule governments wholly or partially under the control of the general state law on these crucial matters. For example, the Utah Constitution grants charter cities home rule powers relating to municipal affairs, but limits their financing ability to the power "to levy, assess and collect taxes and borrow money, within the 1imits prescribed by general law."7 The California constitution places special assessment financing by home rule cities under the general law, unless there is a $4 / 5$ vote of the city councll to override. 8

Similarly, where the constitution directs the legislature to formulate the limits of home rule, statutory provisions often restrict cities or counties from self-government in certain areas.

6olo. Const. Art. $\mathrm{xx}, \$ 1$. ${ }^{7}$ Art. XI, 55. Emphasis added. ${ }^{8}$ Art. XVI, 19 . 
Montana statutes, for example, require home rule citles to follow the general law in matters of "budget, finance and borrowing powers." $" 9$

Regardless of the type of home rule provision, it should be stressed that home rule applies only to matters of "local selfgovernment" and "local concern." In all states, matters of "general" or "statewide" concern are under the jurisdiction of the state leg1slature. On a question deemed to be one of statewide concern, even home rule cities with the broadest constitutional powers have no authority to act in a manner inconsistent with legislative enactments. For obvious reasons, there has been a great deal of litigation as to what constitutes a "local" as distinguished from a "statewide" concern, with results that vary widely from case to case.10 However, the furnishing of utility services has generally been held to be a local affair within home rule powers.11

States also vary as to which local governments are granted home rule powers. Some states grant home rule powers to all general purpose government units, either directly by the constitution or by legislative implementation of a constitutional directive. Whatever

9Mont. Rev. Code \$7-1-114; see also: N.D. Cent. Code \$40-05-01

10See Antieau, Municipal Corporation Law, \$\$3.21-3.40 (1980)

${ }^{11}$ For two recent cases, see Apodaca v. Wilson, 86 N.M. 516, 525 P.2d 876 (1974); Hawailan Govt. Employees Assn. v. County of Maui, 576 P.2d 1029 (Hawail 1978). 
the scope of the home rule power in those states, it inheres in every city without the need for further local action. For example, an Oregon statute provides: "Except as Iimited by express provision or necessary implication of general law, a city may take all action necessary or convenient for the government of its local affairs." 12

Other states permit adoption of home rule by local option. Some offer this option only to citles and towns of a certain size. 13 In many cases cities or counties may acquire home rule by adopting a charter setting forth a framework for local self-government; 14 in other cases, they may accept home rule elther with or without a charter. 15

Since state constitutional or statutory provisions, and not local charter provisions, are the ultimate source of home rule authority, the absence of charter language specifically authorizing geothermal activities does not necessarily signify that the local unit is without authority to act in this area. However, charters frequently do contain express limftations on local powers which might affect geothermal activities, particularly in relation to financing matters; to alter or remove them would require a charter amendment approved by local voters.

120re. Rev. Stat. $\$ 221.410$.

13E.g., Colo. Const. Art. XX, 56 (cities with a population of 2,000 or above); Texas Const. Art. XI, $\$ 5$ (5,000 or above).

14E.g., Utah Const. Art. XI, $\$ 5$.

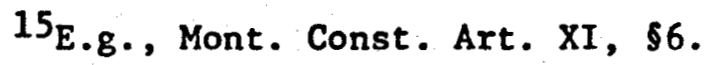


b. SPECIAL DISTRICTS

Special districts are units of local government created to carry out a single or a limited number of functions, In contrast to general purpose governments such as citles and counties. Districts may be formed only pursuant to statute and have only those powers granted by the statute; there are no "home rule" districts.

Some districts are created directly by the state legislature under special legislation defining their boundaries, purposes, powers and operational procedures. In many other cases, the legislature enacts a general enabling statute providing local authority to form a particular type of district. The statute defines the permissible purposes, procedures and powers of the district, and may establish territorial constraints on formation, but the district is actually created only by local action taken to Implement the statutory authorization.

General enabling statutes exist in most states for special districts to perform utility functions, and many water districts and public utility districts are in operation pursuant to these authorizations. In some states, such as California, organizers of a water system may choose among a number of different statutes providing parallel but different powers and procedures for a water district. 16

16 See: General Comparison of Water District Acts, Cal. Dept. of Water Resources Bulletin 11 1 -77, 1978. 


\section{EXISTING AUTHORITY FOR GEOTHERMAL SYSTEMS}

The general law in many states currently grants express statutory authority for local governments to provide some types of utility service. To determine whether existing grants provide adequate authority to develop geothermal heating systems, one must examine both the type of services covered and the scope of local government activities permitted in connection with those services.

\section{a. TYPE OF SERVICES COVERED}

As of this writing, only a few states explicitly authorize local governments to provide geothermal services. Oregon has adopted a comprehensive Geothermal District Heating statute. 17 Idaho grants counties authority to develop "geothermal energy systems;"18 cities in Colorado have authority to acquire and construct "geothermal systems."19 In addition, Nevada authorizes districts to "develop natural sources of energy for and supply the energy for space heating."20 A number of states authorize "heating services" or "heating systems".

170re. Rev. Stat. $\$ 523.020$ et. seq.

18 Idaho code $831-868$. In addition, Idaho has recently clarified its general statutes authorizing clties to establish domestlc water systems and Issue bonds for waterworks to include facilities supplying water "at any temperature for space heating or cooling." See Idaho Code $\$ \$ 50-323,50-1021,50-1029$, and discussion below.

${ }^{19}$ Colo. Rev. Stat. $31-15-707$. While the language of the statute is somewhat ambiguous, it appears to apply to geothermal direct heat systems as well as to geothermal electricity generation.

$20 \mathrm{Nev}$. Rev. Stat. $\$ 318.1175$. 
In general, without mentioning geothermal, 21 and almost all states authorize one or more types of public water system. 22 In addition, some states simply authorize certain local governments to provide "utilities," without specifying the types of utility services included. 23

Both in analysing existing geothermal statutes and in considering new legislation authorizing geothermal heating systems, it is important to note the types of local entities to which the authorization applies. Oregon's statute, for example, applies to incorporated cities and to "comunities" which may wish to incorporate for the purpose of supplying their inhabitants with geothermal heat. 24 The Idaho statute mentioned above applies only to counties, 25 while Nevada authorizes only General Improvement Districts to develop and supply energy from natural sources for space heating. 26 Additional questions may arise as to the scope of activities which such entities may undertake in furtherance of their general authority to provide geothermal heating services, as will be discussed below.

${ }^{21}$ E.g., Alaska Stat. $\$ 29.48 .030 ;$ N.D. Cent. Code $\$ 40-33-01$; Ca1. Pub. Ut11. Code \$\$10001-10002; S.D. Comp Laws \$9-39-1.

${ }^{22}$ E.g., Ore. Rev. Stat. $\$ 261.305$; Colo. Rev. Stat. $\$ 30-20-402$; Wyo. Stat. 115-7-101.

${ }^{23}$ E.g., Ariz. Rev. Stat. \$9-511: Nev. Rev. Stat. $\$ 266.285$.

24 Ore. Rev. Stat. $\$ \$ 523.020,523.030$.

${ }^{25}$ Idaho Code $831-868$. See note 18 supra.

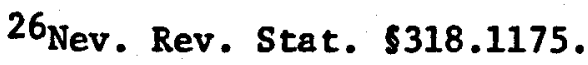


In states whose statutes include "heating" in general among the utility services which local governments are authorlzed to provide, ${ }^{27}$ explicit authority for geothermal heating probably is not required (although it may be desirable from a policy perspective to eliminate any possible uncertainty). However, in cases where a proposed geothermal system is intended to provide both heating and cooling, it is not clear that such language alone -- or for that matter, the language of the Oregon, Idaho and Nevada statutes -would confer adequate local authority. Although the cooling process is necessarily a function of the geothermal heat supplied, the rule that grants of authority to local governments are to be narrowly construed might limit a city or county's freedom to undertake functions not within the literal language of the statutory grant.

As noted above, almost all states authorize local governments to operate water systems, many under statutes using broad language such as water "for all purposes"28 or "for any beneficlal use."29 This kind

27Unlike cities, general law counties rarely have statutory authority to operate utilities other than water systems. However, a few states grant counties the same authority as cities (see, e.g., N.M. Stat. \$15-36A-1); some authorize counties to supplement clty utility services in unincorporated areas, or to exercise utility functions transferred by clties or approved by county voters (see, e.g., Alaska Stat. $\$ 29.33 .25)$; and some, as evidenced by the Idaho geothermal statute clted above, authorize only counties to perform specified utility functions.

${ }^{28}$ E.g., Wash. Rev. Code $\$ 35.92 .010$.

${ }^{29}$ E.g., Cal. Water Code $\$ 31000$. 
of language could be construed to include geothermal systems for heating, cooling and process purposes, and some legislatures have defined geothermal resources (or at least shallow, low-temperature resources) as "water" for regulatory or ownership purposes. However, neither the literal reference to water nor legislative definitions in other contexts should be taken as conclusive of the authority conferred for local utility operations. Although geothermal resources are treated 11ke "water" in some cases (and 11ke "mineral" in others), most states have declined to characterize geothermal as either water or mineral, and appear ready to subject it to different rules than apply to either of these categories where policy considerations dictate separate treatment.

Another reason to exercise caution in relying on a characterization of geothermal as "water" is the history of municipal control over the public water supply. Water for domestic uses is essential to Iife and closely connected to questions of sanitation and public health. Citles have traditionally played an important role in providing water and sewer service to their inhabitants and In maintaining a water supply for fire protection. Accordingly, they have accrued special powers in relation to water systems, as evidenced by provisions in many state constitutions which eliminate the need for voter approval or raise the debt limit for water systems while applying it to other types of utility facilities. 30 In 30E.g., Colo. Const. Art. XI, \$6; Mont. Const. Art. VIII, $\$ 10$. 
interpreting water system authorizations, courts may hesitate to transfer these powers wholesale to local government activities which involve water only as a medium for supplying heat, and not as a commodity indispensable for the public welfare.

On the other hand, although in function a geothermal heating system is more similar to an electric or gas system than to a domestic water system, the operational needs of a geothermal system have much in common with those of a water system. A state legislature could rationally decide that local government powers over water supply would be useful for geothermal as well, and at least one has already done so. The Idaho legislature chose to grant municipal authority for geothermal systems by broadening the definition of water under its domestic water system statute. Under the amended statute, "domestic water system" includes "a public water system providing water at any temperature for space heating or cooling, culinary, sanitary, recreational or therapeutic uses."31 The statute, which applies only to cities, thus extends all city power over water system operation to geothermal systems as well.

31 Idaho Code \$50-323, emphasis added. The National Conference of State Legislatures, a leading proponent of legislative reform in geothermal matters, has recommended similar legislation in New Mexico, Nevada, Utah and Washington. 
Where the authorizing statute speaks neither in terms of heat nor water, but only of "utility" services in general, there is no abvious reason to suppose that geothermal services would be excluded. In such cases, "utility" definitions found elsewhere in the law of the state may provide some evidence of legislative intent (although again, they should not necessarily be considered conclusive on the authorization question). For example, under the Nevada statute a city may provide for "any utility."32 "Utility" is not defined in that section, but in the law defining the jurisdiction of the utility regulatory commission, "public utility" functions are defined to Include the delivery of heat. 33

b. SCOPE OF ACTIVITIES AUTHORIZED

The discussion so far has focused on the authority of local governments to engage in utility services which could include geothermal heating. This section briefly examines the nature of the activities which they may be authorized to undertake in connection with such services. 34 Depending on local conditions and the Institutional arrangements selected, relevant activities could be as

32 Nev. Rev. Stat. $\$ 266.285$.

${ }^{33} \mathrm{Nev}$. Rev. Stat. $\$ 704.020$.

${ }^{34}$ For a detailed discussion of some of the issues ralsed here, see Kramer, W.K., and Hamer, M., "The Role of Municipalities in Geothermal Resource Development" (Rocky Mountain Mineral Law Foundation; January 1977). Although this article focuses on municipal authority for geothermal power generation under California law, much of the discussion is relevant to non-electric activities and illustrative of issues $11 \mathrm{kely}$ to arise in other states as well. 
varied as acquisition of land and resource rights, exploration and fleld development, and construction and operation of production and distribution facilities -- or they could be as limited as the purchase and distribution of heated flulds from an independent resource supplier. The scope of approprlate public entity activities in any particular case will of course depend on many factors, includIng the matters discussed here and varlous financing considerations to be addressed subsequently.

The power of public entities to acquire land and resource rights such as those needed for geothermal development is general and well established. Citles, counties and districts are universally granted the power to own land and other property for public purposes. In addition, many utility enabling statutes contain inclusive language authorizing the entity, for example, to "condemn and purchase, purchase, acquire, [or] lease . . all lands, property, property rights, water, water rights."35

The power of eminent domain, which is the power to acquire private property for public use by condemnation, is generally considered essential for utility systems and is commonly granted to privately owned regulated utilities as well as to public entities. Cities, counties and districts operating utilities are also generally

35Wash. Rev. Code $\$ 54.16 .020$. 
granted the power to condem land and other property rights outside their boundaries for utility purposes. 36

Beyond these general powers in relation to property acquisition, state statutes vary significantly in the nature of activities which they authorize local governments to undertake in furtherance of utility functions within their jurisdiction. For example, some authorize local units to "provide" utility services, 37 others to "acquire" utility works and systems. 38 Where only these powers are mentioned, it is not clear that the entity would have the power to develop or construct a new system, although some courts might imply such authority as necessary to carry out the authority actually granted. Even where the statute authorizes local governments to "construct" facilities as well as to acquire them or to provide services, it is questionable whether such language would be interpreted to allow participation in risk-oriented exploration or development activities which typically precede the construction of a geothermal utility system.

Other statutes tend to be more inclusive in their language. Oregon's constitutional provision authorizing cities to form public 36E.g., Ore. Rev. Stat. \$261.305: Ariz. Rev. Stat. \$9-511.

37E.g., a city may "provide, by contract, franchise or public enterprise" for any utility. Nev. Rev. Stat. \$266.285.

${ }^{38}$ E.g., Colo. Rev. Stat. \$35-15-707. 
utility districts empowers such districts to "acquire, develop and/ or otherwise provide for a supply of water." 39 In Montana cities may "establish, build, construct, reconstruct or extend" a water supply and/or distribution system. 40 Idaho's water system authorization allows cities to "establish, create, develop, maintain and operate" systems to provide for domestic water "from wells, streams, water sheds or any other source;"41 its new statute authorizing counties to undertake geothermal energy systems contains equally broad language, but does not specify the sources from which geothermal fluids may be developed.42 A South Dakota statute grants to cities the power to "establish" plants and equipment for the production or transmission of steam, heat or refrigeration." 43 This language clearly could be construed to permit necessary antecedent activities such as exploratory and test well drilling. 44

390re. Const. Art. XI, $\$ 12$.

${ }^{40}$ Mont. Rev. Code $87-13-4301$.

${ }^{41}$ Idaho Code $850-323$.

42Idaho code \$31-868: " . . to establish, create, develop, maintain and operate geothermal energy systems for heating."

${ }^{43}$ S.D. Comp. Laws $\$ 9-35-10$.

${ }^{44}$ See, e.g., Kramer, W.K., and Michael Hammer, supra note 34. 
A number of citles and one county have been involved to date In developing local geothermal systems. These include the cities of Boise, Idaho; Klamath Falls, Oregon; Susanville and E1 Centro, California; Pagosa Springs, Colorado and Monroe, Utah; and the county of Madison, Idaho. These entities appear to be satisfied of their authority to participate in the early stages of resource confirmation and field development as well as distribution under the laws of their states. As just noted, Idaho statutes for both cities and counties broadly authorize these local units to "establish, create [and] develop" water or geothermal systems. Oregon's geothermal heating district statute provides that incorporated cities "may provide geothermal heating services" and shall have the power, among specified others, to "do all . . acts and things which may be requisite, necessary or convenient in carrying out the objects of the district." 45 The California Constitution states that cities may "establish" public works to furnish their inhabitants with heat. 46 Whether courts would conclude that these various formulations support the activities undertaken is an open question at this point, but they do serve to 1llustrate the range of language to which local governments can presently look for authority to engage in geothermal resource development.

\footnotetext{
${ }^{45}$ Ore. Rev. Stat. $\$ \$ 523.020,523.040$ ${ }^{46}$ Art. XI, $\$ 9$.
} 


\section{B. TERRITORIAL ISSUES}

Geothermal energy must be developed where it is found, and Its heat content utilized within geographic limits defined by resource characteristics and economic constraints. Nelther the location of a resource nor its approprlate service area will necessarlly coincide with the territorial boundaries of an existing local government entity. If such an entity is to develop or operate a geothermal system, it must nevertheless possess legal authority to act where the resource Is found and/or where it will be distributed.

One way of ensuring such authority would be to create a new governmental unit whose powers and boundaries coincide with the needs of the geothermal system. It is unlikely that a new general-purpose city or county would be created for this purpose, but a new special district might well be. A new district might be tallored to the geographic boundaries of an avallable resource and its potential service area either under existing general enabling legislation or by special act of the legislature. Special districts are usually territorially non-exclusive; that is, they may overlap all or parts of the area of other governmental units. Enabling laws also allow many districts to include non-contiguous areas, a useful feature for projects involving the development of discrete geothermal fields or service to geographically separated areas such as industrial parks, shopping centers, resort complexes or new residential subdivisions. 
Some existing enabling statutes for water and utility districts impose territorial restrictions, often in relation to city and county boundaries. For example, some types of districts may include only territory within one county. 47 Some statutes provide that if any part of a city is included within a district, the entire city must be included. 48 Some prohibit the inclusion of any portion of the territory of an incorporated city. 49

An alternative to creating a new entity based upon territorial considerations is to utilize an existing city, county or district as a structural framework. The use of an existing entity raises several territorial issues addressed below, Including:

1) the entity's power to own and acquire property beyond its existing boundaries;

2) the entity's authority to provide services beyond its boundaries;

3) the methods available to alter or extend existing boundaries to encompass areas integral to a geothermal system; and,

4) the entity's ability to provide heating services to some areas of the community but not to others.

E.g., Wash. Rev. Code \$54.08.010.

48E.8., Cal. Water Code $\$ 71071$; Ore. Rev. Stat. \$261.110.

49E.8., Wyo. Stat. \$41-10-102; Cal. Water Code \$15701. 
1) Legislation authorizing cities and counties to operate utilities generally grants the power to own and condemn property where necessary for utility purposes outside their boundarles. 50 Water and utility districts usually have the same power. 51

2) Such legislation also generally authorizes cities to furnish services outside their boundaries. 52 Where it is not expressly authorized, this power is sometimes inferred.53 However, a common limitation is that one city may not supply customers within the boundarles of another city which does not consent. 54 other states limit service outside the entity's boundaries to sales of "surplus."155

Counties typically function mainly in relation to unincorporated areas within their boundaries, and are also comonly restricted from supplying utility customers within incorporated cities without the cities' consent. However, in some cases cities may either transfer their powers over utility activities or contract for services, so that a county may provide services within city territory as well as within unincorporated areas beyond city boundaries. 56 50E.8., Wyo. Rev. Code \$15-7-101; Ar1z. Rev. Stat. \$9-511. 51E.g., Ore. Rev. Stat. \$261.305; S.D. Comp. Laws \$46-16-42. 52E.g., Mont. Rev. Code 87-13-4312; Co10. Rev. Stat. \$31-15-709. 53See: Antieau Municipal Corporation Law, \$19.02. ${ }^{54}$ E.8., Cal. Const. Art. XI, 19; Tex. Rev. Civil Stat. Art. 1108(3).

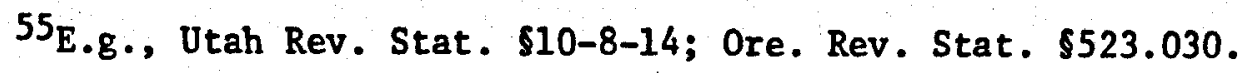
${ }^{56}$ E.8., Alaska Stat. $\$ 29.33 .350$. 
However, county-operated utility systems are not common. 57

Utility services are more typically provided by cities, which of ten serve both their own citizens and unincorporated county areas outside the city limits, and by special districts, which may serve all or a portion of a county, possibly including one or more cities. Districts generally do not serve customers outside their boundaries, although some are expressly authorized to sell surplus to such customers. 58

3) Where a city or district lacks authority to serve customers and/or to own or condem property outside 1ts boundarles, it may be able to achleve those objectives by annexing the territory where the geothermal resource or potential customers are located. Like other powers discussed here, the power to annex territory ultimately resides in state legislatures, but is frequently delegated to local governments subject to varfous conditions specified by state law.

Most states require that at least some portion of the territory to be annexed be adjacent or contiguous to the territory of the annexing entity. 59 Some states allow local governments to annex territory of an adjacent municipality or limited purpose district; others do not. In any case, statutes and court decisions

\footnotetext{
57 Exceptions are found in Hawail (see Haw. Stat. \$54-1) and Colorado (see Colo. Rev. Stat. \$30-20-401).

${ }^{58}$ E.8., Mont. Rev. Code \$17-13-2218.

${ }^{59}$ See, e.8., 56 American Jurisprudence 2d, Municipal Corporations, $\$ 69$.
} 
typically require that there be some reasonable basis for annexation. Depending on the jurisdiction, this standard may be satisfled, for example, if annexation is required for "muntcipal purposes" such as proper police or sanftary protection or extension of streets, sewer, water or other utility systems, or if the annexing entity can offer comparable or superior services or other benefits whose costs should equitably be shared by the adjacent territory. 60 While annexation conditions vary from state to state, most appear sufficiently broad to permit annexation for most purposes which might be served by a geothermal heating system.

Procedures for annexation also vary among jurisdictions. Where the legislature has delegated annexation authority to local governments, proceedings are sometimes initiated by resolution or ordinance of the annexing body, and sometimes by petition of a specifled percentage of property owners or voters in the territory to be annexed. 61 statutes typically provide for public hearings, and some require that proceedings be terminated upon sufficient protest by those whose property is proposed to be annexed, while others mandate an election in certain circumstances. 62 Annexation of territory by special districts typically follows the same procedure as formation of the district. 63

60Id., \$\$65-66.

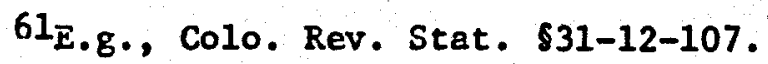

62 Id., 831-15-112.

${ }^{63}$ E.g., Utah Code $87-6-25$. 
In relation to other methods of ensuring public entity jurisdiction for geothermal heating services, annexation may be a cumbersome process, particularly where other local political considerations come into play. However, it should be examined as one option where the characteristics of a geothermal system require development activities or service beyond the inftiating entity's existing boundaries, and necessary authorization cannot otherwise be found.

4) Where system characteristics dictate service within only a portion of the territory of an existing local entity, other considerations arise. The issue here is essentially political rather than legal, and arises primarily in the context of system financing: where the appropriate geothermal service area reaches only part of the population, can or should the financing burden be placed on the local entity as a whole, or only on those of its inhabitants who will receive geothermal heating services?

Most states provide for the establishment by cities, counties and districts of "local improvement districts" for the purpose of making improvements in a particular area to be financed by special assessments on property within the area and bonds secured by assessment 11ens. 64 Many states also authorize the creation of special taxing districts within a clty or county to provide services within a portion of the entity, which are to be pald for in whole or part

64E.g., Idaho Code \$50-1701 et. seq.; Wyo.. Stat. \$41-10-129. 
by additional property taxes and/or by bonds backed only by the taxable property within the taxing district. 65 The purposes for which such districts may be formed are often specified. For example, in California a portion of a city may be formed into a spectal tax district for maintenance and operation (but not for construction or acquisition) of a public utility. 66

Use of one of these methods would allow a portion of an existing entity to be served by a geothermal system at little or no cost to the rest of the population. Alternatively, providing geothermal heat to even a part of the area may be percelved as an appropriate public purpose sultable for financing through the resources of the population as a whole. This may be particularly true where the area served includes public bulldings, a comercial center or an Industrial area integral to the local economy, or where system revenues support other city services.

65 E.g., Utah Code $\$ 10-8-3$; Cal. Water Code $\$ 30000$, et seq.; Alaska Stat. $\$ 29.63 .090$.

${ }^{66}$ Gov. Code $\$ 60000$. 


\section{Formation and Management Structure}

\section{FORMATION}

Where a city or county has the authority to undertake a geothermal system, It may often establish a geothermal utility simply by ordinance or resolution of its governing body. However, some statutes require voter approval before a city or county may construct or acquire a public utility, 67 at least unless the proposed utility is authorized by the city charter. 68 Existing districts initially formed to carry out other functions may need to repeat the formation process in order to add geothermal activities.69 In any case, voter approval is usually required before bonds may be issued to finance a new system. 70

New districts are sometimes created at the state level, by enactment of special enabling legislation. More often they are created at the local level pursuant to general enabling statutes. Formation procedures are generally initlated by petition of a specified

\footnotetext{
67E.g., Ariz. Rev. Stat. \$9-514; Mont. Rev. Code \$7-13-4301. In some cases an election is required only if protests are filed by a specified percentage of the property owners. See, e.g., Nev. Rev. stat. $\$ 266.290$.

68Wash: Rev. Code $\$ 35.92 .070$.

69E.g., Utah Code \$11-23-25; Nev. Rev. Stat. 318.077.

70The implications of voter approval requirements in the financing context will be discussed further in a subsequent section.
} 
percentage of residents or property owners within the area to be included. 71 In some states, formation may also begin with a resolution of the governing body of a city or county. 72

Following public notice of the district proposal, hearings are held and/or affected landowners are granted an opportunity to file protests. In some states, the filing of protests by a majority (or sometimes, by a minority) of landowners will terminate the proceedings. 73 In others, hearings or public protests may result in revision of the proposed district boundaries by the establishing authority.

Some states require approval by a state or county agency as a prerequisite for district formation. 74 Voter approval is required as the final step under most statutes, 75 although a few permit a city or county authority to establish the district without an election, absent sufficient protest, ${ }^{76}$ and a few others grant a state agency the final authorfty to establish a district. 77

71E.g., Wyo. Stat. \$41-10-104; Idaho Code \$42-3204.

72E.g., Utah Code \$17-6-2; Wash. Rev. Code \$54.08.010.

73 E.g., Nev. Rev. Stat. $\$ 318.070$ (majority protest bars formation); Utah Code $\$ 17-6-2$ ( $25 \%$ protest bars formation).

${ }^{74}$ E.8., Cal. Gov. Code $\$ 58000$ et seq.

75 E.g., Cal. Water Code \$71060; Idaho Code \$42-3207; Mont. Rev. Code \$7-13-2214; Ore. Rev. Stat. \$261.130; Wash. Rev. Code \$54.08.030; Wyo. Stat. \$41-10-107.

76E.8., Nev. Rev. Stat. \$318.070; Utah Code \$11-23-11.

77 E.8., S.D. Comp. Laws \$46-16-16. 


\section{MANAGEMENT STRUCTURE}

Many munfcipal utilities are operated as departments of the city or county government, under direct control of 1ts governing body. Some states provide the option of adopting an alternative structure under which utility systems are managed by a separate appointed or elected utility board. 78 The board generally has full authority to establish operating policies and set rates, although rate policies are sometimes subject to review by the governIng body. 79 In Hawail, state law mandates counties to establish appointed boards of water supply to manage and operate their water systems. 80

Special districts are independent entities, governed by their own boards. Board members are generally elected either at large or by subdistrict, 81 but may also be appointed, and may include members representing cities included within the district. 82 District boards ordinarily have full control over the policy and administration of the district, including its financial affairs and the appointment of officials and hiring of employees.

78E.g., S.D. Comp. Laws \$9-39-6; Alaska Stat. \$29-23-340.

${ }^{79} \mathrm{E} .8$., Wyo. Stat. $\$ 15-7-401$.

80 Hawal1 Stat. $\$ 54-12$.

81E.g., Wash. Rev. Code \$54.12.010; Idaho Code \$42-3207.

82E.8., Utah Code \$17-6-3.1. 
It is not uncomon to establish utility districts whose geographic boundaries are coterminous with those of a city or county. 83 This may be done where a city or county itself lacks authority to provide certain services which the district can undertake. Often, the purpose is to create a separate entity and separate governing structure in order to maximize administrative capabilities by removing an essentially commercial operation from the political processes of local government. 


\section{Public Utilitity Regulation}

Under existing law in most states, the functions performed by geothermal distribution systems are 1ikely to be defined as "public utility functions subject to the jurisdiction of state utility regulatory commissions. 84 For investor-owned utilities, commisston jurisdiction results in comprehensive regulation of market entry and extension of service areas, facility siting, adequacy of service, financing and accounting practices, rates charged to customers and allowable rate of return to utility investors.

Publicly owned utilities operated by cities, counties and public districts are generally exempted from all or part of the regulatory scheme, 85 on the theory that their customers are sufficiently protected by the fact that utility rates and policy are set by politically responsible public officials. Of the western states, only Montana includes publicly owned utilities within the full regulatory scheme. ${ }^{86}$

${ }^{84}$ See Nimmons, J., et al., "Overview of State Public Utility Regulation Impact on Geothermal Direct Heat Applications (EarI Warren Legal Institute; Apr11 23, 1979) and Nimmons, J., "State-by-State Analysis of Public Utility Laws Affecting geothermal Direct Heat Applications" (Earl Warren Legal Institute; June 26, 1979). See also discussion at pp. 52-56, infra.

${ }^{85}$ Id.

86 Mont. Rev. Code \$69-3-101. 
Where some customers are not in a position to control utility policy through political means, the exemption may be limited accordingly. Colorado, for example, exempts municipally operated utilities from state utility regulation only as to service provided within their own borders: service to customers beyond city boundaries Is subject to state utility commission jurisdiction and treated like privately offered utility services. 87 Similarly, in Wyoming commission jurisdiction over municipally owned utilities applies only to service beyond muntcipal boundaries 88 (and as to water systems, not even then, although the commission is empowered to hear and resolve disputes over rates and service between the city and its outside customers.) 89

\section{Utility comission responsibility for overall statewide} utility service is reflected in some other imitations on exemptions for publicly-owned utilities. Alaska requires city or county utilities to obtaln certificates of public convenience and necessity, although they are otherwise exempt from regulation except where they are in competition with another utility. 90 In New Mexico the state

${ }^{87}$ City and County of Denver $v$. Public Utilities Commission, 181 Co10. $38, \frac{C}{507 \text { P. }} \cdot \frac{1}{871(1943) . ~}$

88 Wyo. Stat. $\$ 37-1$.

89Wyo. Stat. \$15-7-461(c).

90Alaska stat. $\$ 42.05 .711$. 
commission must approve the acquisition of an existing utility by a municipality where the purchase is to be financed through revenue bonds. 91 North Dakota exempts utilities operated by cities, counties and other political subdivisions from commission jurisdiction over rates, contracts and service, but not otherwise.92 Washington has similar provisions for municipal utilities.93 Several states provide that municipal utilities may elect to be governed by the state regulatory scheme. 94

91N.M. Stat. \$3-23-3.

92N.D. Cent . Code \$49-10-01.1.

93 Wash. Rev. Code $\$ 80.04 .500$.

94E.g., Alaska Stat. $\$ 42.05 .711$. 


\section{PRIVATE ENTITIES: COOPERATIVES AND PRIVATELY OK:NED COMMEPCIAL ENTERPRISES}

\section{A. Cooperatives}

\section{INTRODUCTION}

In general, geothermal district heating will serve a limited population of users within a defined geographical area. The larger and more diverse the user group, and the more extensive the service territory, the more likely it is that the use of public sector entities like those discussed above will justify the political and bureaucratic costs involved in their formation and operation. Where the user group is smaller and more homogeneous and the service territory more limited, private entities may provide simpler, more flexible mechanisms for geothermal heating.

Cooperatives comprise one class of private entities potentially sultable for these purposes. In the broadest terms, a coope:ative is "a democratic association of persons organized to furnish themselves an economic service under a plan that eliminates entrepreneur profit and provides for equality in ownership and control."95 Cooperatives in general are not restricted in the type of functions they may perform, and the law with respect to cooperatives has tended to develop along functional 1ines. Statutes enacted during the $1920^{\prime} \mathrm{s}$ promoted agricultural product marketing through cooperative enterprises.

95 Pachel, Israel, The Organization and Operation of Cooperatives. Joint Committee on Continuing Legal Education of the American Law Institute and the American Bar Association, 1970, p. 6. 
Cooperative apartments had their beginnings during the same period, and cooperative housing concepts have expanded more recently under special legislation for condominiums.

Cooperatives have also played a significant role in the development of certain utility services in the United States, and thus can provide historical models for member-owned geothermal enterprises controlled by and providing heating services to their members and perhaps to others. The Rural Electrification Administration, established in 1935, encouraged distribution of electricity to near1y four million farms through government financing of cooperative associations. Since 1949, this cooperative program has been used to extend telephone service to rural areas. State legislatures and the U.S. Congress have also accorded special consideration to cooperatives by granting exemptions from regulation and taxation in order to advance the public welfare through private self-help. Independent of specific government programs, cooperatives have long been used for irrigation and domestic water distribution.

Given their history, cooperatives may be able to take advantage of a favored position to create and operate certain types of geothermal heating systems for which other entities are less suited. The nature and attributes of cooperative organization therefore bear further examination in the geothermal context. 


\section{FORMATION AND ATTRIBUTES OF COOPERATIVES}

Unlike local governments whose powers are strictly limited to those granted by constitution or statute, private entitles are generally free to engage in any lawful activity promoting the purposes for which they are formed. In the case of cooperatives, the central inquiry is not whether specific authority exists to undertake particular activities, but what procedural avenues for formation exist and what restrictions must be observed in order to retain the tax and regulatory advantages often attendant on cooperative status.

As is true of the public entities already discussed, the legal framework governing methods of formation, attributes of cooperative status and restrictions on cooperative activities varies from state to state. Some jurisdictions provide detailed statutory schemes for cooperatives, while others treat cooperatives under general provisions governing nonprofit organizations or under their general incorporatior laws. In addition, cooperatives may be formed as unincorporated associations, subject to ordinary rules governing partnerships and similar associations. Each of these possibilities is discussed briefly below.

\section{a. COOPERATIVE STATUTES}

Many states have speclal statutes governing cooperatives formed for specifled purposes. However, existing speclal purpose statutes do not contemplate geothermal heating activities. For 
example, statutes governing agricultural cooperatlve associations typically sanction groups organized exclusively for marketing or selling agricultural products or for related agricultural activities. 96 Similarly, cooperative housing statutes are designed for the acquisition and operation of housing complexes in ways not relevant for district heating purposes. ${ }^{97}$ While many states have special statutes governing rural electric cooperatives engaged in utility activities, they are specifically limited to rural electricity distribution, 98 and are inappropriate for geothermal heat distribution.

Apart from these special purpose statutes, however, most states have statutory schemes for the formation of general-purpose cooperatives as entities distinct from ordinary corporations or from nonprofit corporations. 99 They usually permit anywhere from three to five persons to form a coop for any lawful purpose, presumably including the development and operation of geothermal heating

${ }^{96}$ E.g., Colo. Rev. Stat. \$ \$7-56-101 to 7-56-133.

97 E.g., Ariz. Rev. Stat. Ann. $\$ 33-551$ to 33-561; Colo. Rev. Stat. \$38-33-101 to 38-33-105.

${ }^{98}$ E.g., N.M. Stat. 1978, Art. 15, "Rural Electrical Cooperatives Act," and Mont. Code Ann., Chap. 18, "Rural Cooperative Utilities."

${ }^{99}$ E.g., N.D. Cent. Code $\$ \$ 10-15.01$ to 10-15.61; Colo. Rev. Stat. \$\$7-55-101 to 7-55-121; Mont. Code Ann. \$335-15-101 to 35-15-507; and Cal. Corp. Code \$\$12200-12956. 
systems. Such statutes grant coops all the powers of corporations generally, 100 all the powers of natural persons, 101 and/or specific powers to sue and be sued, to buy and sell property, to borrow money, and to make contracts. 102 Where a state's general corporation law does not extend to cooperative associations, coop statutes themselves generally confer limited liabllity upon coop members. 103

\section{Cooperative statutes typically distinguish coops from} other forms of business organization in terms of the purposes for which they are formed, the voting rights of members, and the distribution of earnings. Statutes usually require that the cooperative business be primarily for the mutual benefit of members or shareholders, that only members vote at meetings and that each have only one vote, and that earnings be distributed wholly or partly In proportion to the amount of business done with members. In addition, statutes often expressly authorize limitations on membership and on the transfer of membership shares.

In keeping with the primary purpose of cooperatives to encourage mutual self-help, many cooperative statutes restrict dealings with non-members. Colorado, for example, requires that at least

100

Cal. Corp. Code $\$ 12205$.

101 N.M. Stat. $1978 \$ 54-4-4$.

102E.g.,Co1o. Rev. Stat. \$7-55-107; Ore. Rev. Stat. \$62.105.

${ }^{103}$ E.g., N.M. Stat. \$53-4-29; Ore. Rev. Stat. \$62.215; N.D. Cent. Code \$10-15-31. 
$50 \%$ of the cooperative's business be with members, 104 and Californla allows distribution of surplus to non-shareholder patrons only If $50 \%$ of the distributable amount is applied toward the purchase of shares.105 New Mexico, where statutory cooperatives are required to be nonprofit, has elaborate provisions for income distribution which strongly encourage coop membership. Under New Mexico law, net savings must be distributed first to surplus, then to dividends on share capital, then to an educational fund to teach cooperation. Any remaining funds go first to member patrons in proportion to patronage, second to non-paid up subscribers and finally, only upon presentation of evidence of patronage, to non-member patrons as credit toward minimum necessary share membersh1p.106 other states allow equal distribution or nember/non-member discrimination as provided in the cooperative by-laws. 107

\section{b. NONPROFIT STATUTES}

In an accounting sense, cooperatives may be operated for profit or not for profit: nothing in the form of organization inherently requires either mode of operation over the other. In the legal

\footnotetext{
104Colo. Rev. Stat. 87-55-101(a). Similar provisions in other state statutes allow dealings with non-members but in no amount greater than the value of dealings with members. See Nev. Rev. Stat. $\$ 81.020(4)$.

${ }^{105} \mathrm{Cal}$. Corp. Code $\$ 12805(\mathrm{c})$.

106 N.M. Stat. $\$ 53-5-31$.

107 N.D. Cent. Code $\$ 10-15-33(3)$ and (4).
} 
sense, the terms "profit" and "nonprofit" have no independent or universal meaning apart from the specific context in which they may be applied. Thus, a statute may define entities formed under it as nonprofit for purposes of exemption from state franchise taxes or antitrust laws, while the same entities might not be considered nonprofit under other laws governing federal tax or state utility regulation exemptions. On the other hand, some organizations may be deemed nonprofit in certain of these contexts although not incorporated under a nonprofit corporation statute. Whether a geothermal cooperative can or should incorporate under a state's nonprofit statute will therefore depend upon the scope of the particular statute and the purposes which the cooperative is intended to serve.

Some nonprofit corporation statutes are not adaptable to geothermal cooperative enterprises. Some expressly exclude cooperative activities from the list of acceptable purposes. 108 Some apply only to organizations engaged in religious, scientific, charitable or eleemosynary activities unrelated to the functions of a heating coop. 109

Other statutes, however, allow formation for any lawful purpose including but not limited to specified charitable, civic

108 See Wash. Rev. Code $\$ 24.03 .015$.

${ }^{109}$ See Nev. Rev. Stat. $\$ 81.290$ to 81.340 . 
or educational activities. Such broad language would not preclude nonprofit incorporation by cooperatives. The Wyoming Corporations Comission, for example, will allow cooperatives to Incorporate under such a statute ${ }^{110}$ provided that 1 ts other requirements are met. Beyond this, some states expressly include "cooperative association" or specified activitles such as water development and distribution among the list of purposes for which a nonprofit corporation can be formed. 111

In states experienced in dealing with cooperative organizations, formation under avallable nonprofit statutes is unlikely to pose special problems. However, where there is no experience under any pre-existing scheme which might cover a geothermal heating cooperative, uncertainties may arise as to methods of formation and regulatory treatment. Again using Wyoming as an example, while nonprofit corporations are generally exempt from securities registration, the Corporations Comission may take a different position with respect to cooperatives in relation to offers of membership shares. 112 Moreover, because the nonprofit statutes often expressly

110wyo. Stat. $\$ \$ 17-6-101$ and 17-6-111. See also Idaho Code $\$ 30-301$ to $30-302$.

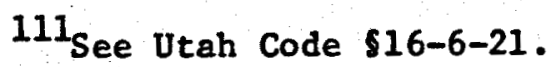

112 The Comission's reluctance to apply the exemption to cooperatives arises from recent experience with out-of-state agricultural cooperatives which have defrauded members. (Personal comunication from Wyoming Corporations Commission staff counsel.) 
forbid the payment of "dividends of any kind" on capital stock, It is unclear whether coops could return patronage dividends to members.113 Wyoming's Corporations Commission counsel suggests that careful drafting to characterize patronage dividends as "refunds" might circumvent the problem, but no Wyoming cases have interpreted the statutes on this point.

\section{c. GENERAL INCORPORATION STATUTES}

Another possible method of organizing a cooperative is under an ordinary business corporation statute. Since these statutes are written for business organizations in general, careful consideration must be given to those matters which particularly affect cooperative status and thus the avallability of regulatory and other advantages.

Cooperatives usually limit membership to those benefitting from the cooperative enterprise, and accordingly restrict transfers of membership shares. Since the law generally disfavors restrictIons on share transfers unless they are reasonable and specifically authorized, most incorporation statutes require that the articles of Incorporation expressly state any such restrictions. 114 Some

113wyo. Stat. \$17-6-102(a)(v111). See also Wash. Rev. Code \$24.03.030; and Utah Code \$16-6-42.

${ }^{114}$ See Co10. Rev. Stat. 87-2-102(1)(1); Idaho Code $30-1-54$ (h); Mont. Rev. Code Ann. \$35-1-202(h); and Utah Code \$16-10-49(1). 
also require that any restrictions on acquisitions of more than one share similarly be set forth. 115 since cooperatives operate on the principle of one share and one vote per member, such restrictions must be stated in the articles to comply with these requirements. Additionally, since general corporation statutes usually contemplate distribution of profits as dividends and do not specifically provide for patronage refunds, a refund plan will have to be included in the articles of incorporation.

\section{d. UNINCORPORATED COOPERATIVES}

Cooperatives need not assume the corporate form, but might function as unincorporated associations. Whether organized formally under a state's partnership law or informally as a loose association of persons acting in concert to provide heating services, such a group probably would possess the legal attributes of a general partnership. Limited partnerships by definition restrict the limited partners' power to manage and control the enterprise, and for that reason are incompatible with cooperative organization.

The legal and practical implications of unincorporated status as opposed to corporate status are not unique to the geothermal setting. They include considerations of taxation, management structure and participant liability common to these forms of 
business organization in general. For example, members of a cooperative operated formally or Informally as a general partnership would not have the benefit of limited liability for the cooperative's obligations, as they would in the case of a cooperative organized as a corporation. (In practice, this distinction may have little significance since the participants' personal exposure in some areas can be minimized by adequate insurance coverage, and since even an incorporated geothermal cooperative may be unable to obtain financing or credit without pledging its individual members' assets as security for the cooperative's obligations.) Other differences between incorporated and unincorporated cooperatives similarly reflect well-established legal priniciples applicable in a variety of non-geothermal contexts, and therefore will not receive special attention here.

\section{REGULATION}

\section{a. SECURITIES REGISTRATION}

As a general rule ownership interests in a business enterprise which are offered for sale are considered securities which must be registered with a state corporation commission. However, some states exempt cooperatives and/or nonprofit corporations from securItles registration under certain conditions. Idaho, for example, exempts nonprofit cooperatives which limit expenditures for the issuance 
of securities in a prescribed manner. ${ }^{116}$ other states exempt nonprofit corporations operated for specified purposes. 117 In adaltion, some states allow the securities combissioner to exempt organizations for which registration is deemed unnecessary for protection of investors. 118 Whether or not an exemption will apply to a given cooperative organization will therefore depend upon the nature of the organization and the statutes, policles, and practices of the state in which it is Incorporated.

In cases where cooperatives must register securfties with the state corporations comission, the procedure requires filing certain information specified by statute, usually including such items as the current financial condition of the organization, outstanding contract obligations, pending litigation, and a profit and loss statement for a specified perlod. However, where utility coops are exempt from public utility commission regulation, securities reglstration may involve not only financial oversight but also operational supervision which might otherwise be performed by a state utility commission. In California, for example, in determining

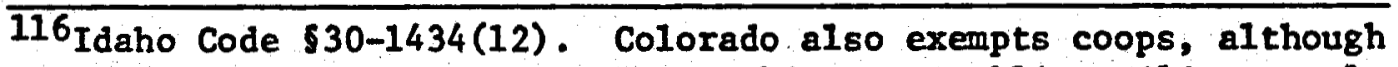
since utility cooperatives are subject to public utility regulation which includes security regulation, the securities exemption may be comparatively insignificant.

117 E.g., Mont. Rev. Code Ann, 30-10-104(a) and Wyo. Stat. $517-4-114$ (a) (v111).

118 Mont. Rev. Code Ann. \$30-10-104(12); Colo. Rev. Stat. $511-51-114$ (1)(1). 
whether a membership offering is "fair, just and equitable" the Corporations Commission requires that mutual nonprofit water companies submit an engineering report showing adequacy of the water system for its proposed use and a Health Department clearance as to the potability of water intended for distribution.119 Commission counsel have indicated informally that comparable requirements probably would be Imposed upon a geothermal heat cooperative. Since the Comission has no experience with such entities there is potential for administrative delay and/or conflict while the Commission's engineering department educates itself on geothermal heating distribution system requirements.

\section{b. PUBLIC UTILITY REGULATION}

Under existing state laws, most private entities distributing heat or water to the general public as their primary business will be subject to comprehensive regulation as public utilities. 120 However, statutes or judicial decisions in some states exempt cooperatives (including certain cooperative water companies) ${ }^{121}$ or nonprofit

119 See Cal. Dept. of Corporations Release 2-C (Mutual Water Companies) and Release 15-C (Membersh1ps).

120For a discussion of the relevance of utility regulation to geothermal direct heat development see Nimmons, John T., "Overview of Public Ut1lity Regulation Impact on Geothermal Direct Applications" (Ear1 Warren Legal Institute, University of California, Berkeley; April, 1979). See also Infra Pp. 52-56.

${ }^{12} 1_{\text {See Cal. Pub. Ut11. Code } \$ 2705 .}$ 
corporations (Including some nomprofit water companies) ${ }^{122}$ from utility regulation, at least where they serve only their own members. 123 Other states exempt utilities (possibly including cooperatives) operating for the benefit of some limited number of customers at rates below statutory maximums. 124

Absent explicit statutory exemptions, the controlling test for public utility status is whether an entity serves or is willing to serve the general public within its appropriate service area. If a cooperative confines its service to members only and does not hold itself out to serve the public at large, it may excape regulation even where no express exemption is avallable. Membership requirements are important in this context. If they are so broad as to effectively Include the general public, characterization

122 See Lockwood Water Users Assoc. v. Anderson (1975) Mont. 542 P.2d. 1217; Ore. Rev. Stat. \$757.005(2).

$123_{\mathrm{Nev}}$. Rev. Stat. $\$ 704.675$.

1240re. Rev. Stat. $\$ 757.005$ (2) (certain nonprofit water systems or systems serving 200 persons or less at rate of $\$ 10 /$ month or less and with annual gross operating revenue under $\$ 20,000$ ); Nev. Rev. Stat. $\$ 704.030$ (nonprofit or cooperative water services if serving 25 persons or less or with gross sales of $\$ 5,000$ or less); Wash. Rev. Code Ann. 880.04 .010 (1977) (less than 60 customers with average annual gross per customer not to exceed $\$ 120$ ). For analysis of public ut1lity regulation in thirteen western states see: Nimmons, John T., "State-by-State Analysis of Public Utility Laws Affecting Geothermal Direct Heat Applications." (Earl Warren Legal Institute, University of California, Berkeley; June, 1979.) 
as a public ut1lity w11l be more l1kely. The fact that the organization operates without profit or returns profits to its members also has been treated as an important element in excluding a cooperative from public utility status. 125

\section{TAXATION}

\section{a. FEDERAL INCOME TAX TREATMENT}

Section $501(\mathrm{c})$ of the Internal Revenue Code exempts some cooperative organizations from federal income tax. Although it does not expressly refer to "heating" or "geothermal" coops, it does exempt "mutual ditch or irrigation companies, mutual or cooperative telephone companies, or like organizations; but only if $85 \%$ or more of the income consists of amounts collected from members for the sole purpose of meeting losses and expenses."126 Electric coops 127 and mutual water companies ${ }^{128}$ have been held exempt under this section, and it seems likely that courts would treat other utility coops similarly so long as they fall within the $85 \%$ rule. ${ }^{129}$

125Garkane Power Co. v. Public Service Co. (1940) 98 Utah 466, 100 . P.2d 571 .

126IRC 5501 (c)(12); emphasis added.

127 Peninsula L1ght Co., Inc. (CA-9) 771 USTC 19401, 552 F.2d 878.

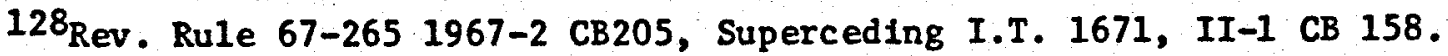

${ }^{129}$ It appears that an exempt coop can also retain funds in excess of those needed to meet current losses and expenses for purposes of expanding services, repaying debt and maintaining reserves without losing its exemption. See $805 \mathrm{CCH}$ Reg. $\$ 1.501$ (C) 12 \3051.087. 
In any case, non-exempt cooperative corporations may also benefit from special federal tax treatment. While ordinary corporations are taxed on net income as determined by deducting business expenses from gross receipts prior to any distribution to shareholders, the IRS allows cooperative corporations to reduce gross receipts by the amount paid in "patronage dividends,"130 so long as recelpts arise from patronage within the taxable year and are distributed within nine months of the end of the taxable year. 131 However, if the cooperative does business with non-members as well as members and does not also return to them dividends in proportion to patronage, the amount of recelpts over costs attributable to nonmember patronage is taxable. 132

Cooperative patrons, on the other hand, must include patronage dividends in gross income, unless the amount is attributable to personal, living or family items.133 This rule could be interpreted

130IRC \$1382(b). "Patronage dividends" are defined in IRC \$1388(a) as ". . - amount paid to patron . . . (1) on the basis of quantity or value of business done with or for such patron (2) under an obIigation of such organization to pay such amount which obligation existed before the organization recelved the amount so paid, and (3) which is determined by reference to the net earnings of the organization from business done with or for its patrons."

131 Reg. $\$ 49849 \mathrm{H} .01$. It also appears that non-exempt coops can retain patronage refunds for certain types of reserves so long as the patron is properly notified of retained earnings credited to his account. See $807 \mathrm{CCH}$. Reg. \$1382-7 $14893 \mathrm{H} .12$.

132 Regs. $\$ 49848 \mathrm{H} .03$

${ }^{133}$ IRC $\$ 1385(\mathrm{~b})(2)$ 
to mean that residential members of a geothermal heat cooperative could exclude patronage dividends from gross income while commerc1al nembers could not. 134

Unincorporated cooperatives are not subject to these corporate tax provisions. Any tax impact therefore will affect coop members as individuals. For member patrons, there would appear to be no reason for treating patronage dividends differently because the coop is unincorporated. Refunds distributed on the basis of patronage should be included in gross income unless attributable to personal, 11ving or family Items. 135 Refunds to members attributable to non-member patronage would presumably be taxable income to the members. The latter income, however, is not taxable to the cooperative, and thus escapes the double taxation which would be Imposed on similar corporate receipts.

134 From the viewpoint of the residential member patron such tax treatment presents an advantage unavallable to ordinary corporate stockholders who patronize their company's business. In the latter Instance any dividends are taxable income irrespective of the portion attributable to the stockholder's patronage. The principal advantage of cooperative membership for comercial customers, on the other hand, arises from potentially lower heating costs rather than tax benefits. Service payments by the comercial customer are presumably deducted as business expenses in the first Instance, and subsequent patronage refunds are thus additional income subject to tax.

135 IRC $\$ 1385$ (b) (2) allowing exclusion of patronage dividends attributable to personal, living or family items does not appear to distinguish unincorporated from incorporated cooperatives. However, we have found no case on this point. 


\section{b. OTHER TAXES}

Property tax is based upon ownership, and normally applies to cooperatives as it does to other property owners. However, states desiring to foster cooperative activities occastonally grant property tax exemptions from which a geothermal heat coop might be able to benefit. 136

State franchise taxes are generally imposed for the privilege of doing business as a corporation, and ordinarily such taxes also apply to incorporated cooperatives as they do to any other corporations. A number of states, however, provide exemptions for various organizations which could include geothermal heat cooperatives.137 Additionally, cooperative statutes wh1ch explicitly impose a tax on cooperatives for doing business and declare all other inconsistent state laws inapplicable, appear to exempt cooperatives from more burdensome franchise taxes imposed upon ordinary corporations. 138

136 North Dakota, for example, exempts from property tax "all fixtures, buildings and improvements owned by any cooperative or nonprofit corporation organized under the laws of the state and used to furnish potable water to its members and customers for uses other than Irrigation of agricultural land." N.D. Cent. Code \$57-62-08(28).

${ }^{137}$ E.8., Utah Code Ann. \$59-13-4 (Following the IRS definition providing that mutual ditch or irrigation companies, mutual or cooperative telephone companies and 11ke organizations with $85 \%$ of income from members for meeting losses and expenses are exempt from franchise tax); Tex. Civ. Stat. Ann. Art. 1396-50.01 \$44 (association organized under Cooperative Association Act exempt from franchise tax and license fees).

138 See N.M. Stat. Ann. \$53-4-43 and 53-4-45 (annual tax of \$5.00). 


\section{B. Privately OWned Commercial Enterprises}

\section{INTRODUCTION}

Unlike cooperatives, whose primary purpose is to furnish services at cost to the members who own and control the enterprise, the entities discussed here would be organized primarily to provide services at a profit to users who neither own nor control the enterprise (or whose ownership and control is incidental to the entity's business purposes).

Existing privately owned utilities provide a variety of utility services including gas, electricity and water to residential and commercial customers throughout the country. These utilities. may or may not be involved in the exploration, development and/or production of the commodities they supply to customers, but all are experienced in marketing, distribution and customer service, and are therefore potential participants in at least some of the activities required for geothermal district heating. Although the major Investor-owned gas and electric utilities in the Western states have expressed 1 imited interest in geothermal heat development and distribution, smaller private gas or electric utilities and local water utilities may provide useful vehicles for geothermal heating. ${ }^{139}$ Where existing entities of this type are not suitable or adaptable for geothermal functions, new ones may be formed.

139For a more complete discussion of gas and electric utilities' view of their Involvement in geothermal heat distribution see: King, $D$. et al., "The Role of Gas and Electric Utilities in Direct Applications of Geothermal Resources." (Earl Warren Legal Institute, University of California, Berkeley; March, 1980.) 
As noted earlier, private entities are generally free to engage in any lawful activity promoting their business purposes, and their authority to undertake particular activities is rarely an issue. Where they are not formed to take advantage of special benefits, as in the case of cooperatives, restrictions on structure, formation and management also assume lesser importance: privately owned utilitles will almost always be organized as for-profit corporations under a general corporation statute, and will be managed like other profit-seeking businesses with appropriate regard for the interests of investors. What will distinguish private commercial enterprises contemplating geothermal heating activities from public entities and from most cooperatives will be the likely prospect of public utility treatment under existing state law, and the implications of such treatment for decisions regarding the nature and scope of business activities. 140

140 The public utility discussion which follows sumarizes the findings of two comprehensive reports previously published by the Ear1 Warren Legal Institute. For a more detailed treatment, including extensive cltations to relevant statutes and judicial decisions in the Western states, see Nimmons, J., et al., "Overview of State Public Utility Regulation Impact on Geothermal Direct Heat Applications" (Earl Warren Legal Institute, April 23, 1979), discussing types of services regulated, scope of activities resulting in regulation, and types of available exemptions; and Nimmons, J., "State-by-State Analysis of Public Utility Laws Affecting Geothermal Direct Heat Applications" (Earl Warren Legal Institute, June 26, 1979), summarizing and analyzing relevant regulatory provisions in each of 16 states known to have geothermal potential. 


\section{STATE PUBLIC UTILITY REGULATION, IN GENERAL}

Each state utility statute defines "public utilities" or "public service corporations" subject to commission jurisdiction. These definitions specify the types of commodities (e.g., electricity, gas, heat or water), the nature of services (e.g., production, distribution, furnishing, or sale of designated comodities), and/or the kinds of entity (e.8., electric corporation, gas corporation, water or heat corporation) which may be accorded public utility status.

However, the fact that an enterprise may supply one of the specified comodities or services will not necessarily subject it to regulation as a public utility. Almost every state's definition imposes the additional requirement that the commodity or service be offered "to the public," "for public use," or alternatively, "for hire" or "for compensation." Although judicial interpretations vary somewhat, these terms reflect the established legal doctrine -especially relevant to geothermal direct heat suppliers -- that states cannot Impose utility regulation upon services which are essentially private in nature and not offered to the public at large, or to some substantial portion of the public.

Having defined the nature and scope of services generally subject to regulation, many state statutes provide explicit exemptions for specified suppliers or uses. In addition to publicly-owned 
entities and certain nonprofit corporations and membership cooperatives discussed above, these exemptions may include small-scale water systems with 1 imited revenues, sales to the producer's tenants, and/or surplus or incidental sales by persons not otherwise engaged In the utility business.

For entities which meet the criteria specified for public utility status and do not fall within an exempt category, the statutes impose a varlety of regulatory measures. About half of the western states empower their utility commissions to control market entry and territorial limits by the issuance of certificates of public convenience and necessity requiring, among other things, a determination that the proposed service is needed and will not duplicate existing services. The comissions generally supervise utility books and accounts, issuance of both equity and debt securitles for financing purposes, and relations with affiliated enterprises. Some control facility siting. All regulate rates charged to customers.

\section{APPLICATION TO GEOTHERMAL HEATING SYSTEMS}

None of the 16 western and gulf states expressly Includes geothermal supply companies, or the furnishing of geothermal heat, In its definition of public utility entities or services. However, 11 of these states do include in their definitions a more general reference to "heat corporations" or the furnishing of heat in some 
form (including steam), and all except South Dakota include water corporations or the furnishing of water in their utility definitions. In addition, several states define public utilities to include "pipeline corporations"; in some cases, these provisions may provide an alternative basis for treating geothermal suppliers as regulated utilities.

A few states qualify their definitions in ways which could be construed to limit or preclude their application to geothermal suppliers. For example, Texas, whose statute does not mention heat or steam suppliers, restricts comission jurisdiction over water suppliers to those furnishing "potable" water. 141 Utah, which defines "water corporations" very broadly, nevertheless limits its definition of "heat corporations" to those furnishing "artificial" heat 142 (an undefined qualification difficult to apply in the geothermal context). And in Arizona, where the statute on its face reaches corporations "furnishing water for .. . public purposes," the state supreme court has held that the term "furnishing" connotes a "transfer of possession," and that no such transfer occurs when water is supplied for heating and cooling purposes, as distinguished from consumptive uses. ${ }^{143}$ The court's reasoning is subject to criticism, but its result appears to exclude low-temperature uses from the Arizona Commission's furisdiction.

${ }^{141}$ Tex. Stats. Art. $1446(c)(4)$.

142 Utah C. $\$ 54-2-1(15)$

${ }^{143}$ See Williams v. Pipe Trades Industry Program of Arizona (1966) 100 Ariz. 14, 409 P. 2d 720. 
Apart from these few qualifications, it is doubtful that geothermal suppliers can avoid regulation based upon the nature of the commodity or service provided, since the furnishing of water and/or heat is almost universally defined as a utility function. On the other hand, certain types of direct applications may be beyond the reach of regulation because they do not amount to "public uses," or because they meet the criteria for statutory exemptions.

Although it appears that no state commission has yet formally addressed the question, traditional practices suggest that an Independent geothermal producer which supplies hot water at wholesale to an unrelated distribution entity may not be deemed to be furnishing services "to the public," and therefore will not acquire public utility status by reason of such activities. 144

Even where sales are made directly to the ultimate consumer, numerous courts have held that the "public use" requirement is not met where a gas or water supplier offers its services to selected users pursuant to negotlated contracts, and does not hold itself out to serve the public at large. Whether this principle will be applied to exclude private developers of limited district heating

144 E.g., Parrish v. Public Ut1lities Commisston (1956); 134 Colo. 192, 301 P. 2d 343; but cf. Cal. Pub. Ut11. C. $\$ 216(\mathrm{c})$, Haw. Rev. Stat. \$264-1, Or. Rev. Stat. \$757.005(1)(a), Tex. Ann. Civ. Stat. Art. 1446c, $\$ 3(c)(4)$, and Utah C. Ann. $\$ 54-2-1(30)$, providing in substance that entities which supply the public directly or indirectly through another entity will be treated as public utilities. 
systems for applications such as Industrlal and office parks, resort complexes, shopping centers or residential subdivisions will depend upon judiclal interpretations in each state and upon the particular circumstances of each case. Some states have refined the principle to provide the specific exemptions noted above for sales of surplus water or heat beyond the primary user's needs or sales "Incidental" to the main business of the supplier, 145 and sales to tenants or employees of the producer. ${ }^{146}$ Nevada, Oregon and Washington expressly exempt small-scale water utilities serving less than a specifled number of users, and with annual revenues below stated dollar amounts. 147

Even if a geothermal utility is not subject to state regulation, there remains a possibility that some form of government oversight may be Imposed at the local level. Municipalities generally have the power to require utilities to obtain franchises for operation within municipal limits and use of local streets and rights of way, and may Impose franchise fees typically calculated as a specified percentage of the utility's gross local revenues.

Where the utility is certified by the state, a municipality

145 Arizona, California, Colorado, Nevada, New Mexico, Oregon and Utah. For cltations to relevant authority, see publications referred to at $n$. 140 , supra.

${ }^{146}$ California, New Mexico, Texas, Utah and Wyoming. Id.

147 Nev. Rev. Stat. \$704.030; Or. Rev. Stat. $5757.005(2)$; Wash. Rev. C. Ann. $\$ 80.04 .010$. 
may not refuse to grant a franchise or Impose conditions inconsistent with state policies. However, where the utility is not subject to state commission jurisdiction, local franchises may Include conditions governing utility service operations and system extensions, and may require municipal approval of utility policies, sometimes including rate policies, as is currently done in the case of cable television systems.

\section{IMPLICATIONS FOR GEOTHERMAL DEVELOPMENT}

For those contemplating even limited geothermal district heating systems, public utility status could present an Initial barrier to market entry and location of facilities. Where utility commissions are empowered to grant or withhold certificates of public convenience and necessity--without which public utilities cannot construct or operate facilitles--the applicant must demonstrate, among other things, that the proposed service is needed and will not duplicate services already available in the area. Existing utilities and others typically have the right to challenge any such showing, and have frequently done so in connection with conventional utility services.

The outcome in such cases is likely to be determined largely by the scope of the existing utility's own certification, and of its actual operations. Such challenges have traditionally succeeded only when the competing utility offers an Identical service or commodty, or the same commodity in a different physical state (e.g., natural vs. 11quefied gas). Where that is the case, a new entrant 
Is typically required to show that the certificated utility has falled to render adequate service at reasonable rates. However, prospective geothermal entrants can probably argue successfully that geothermal heating services are not identical with conventional services offered by existing gas or electric utilities. In general, courts and commissions have allowed new entry of firms which of fer substitute fuels and have not construed the monopoly franchise so broadly as to preclude all forms of competition, but the outcome in any specific case will depend upon the particular facts presented.

Apart from market entry, rate regulation presents the most serious concern for geothermal suppliers considering integrating exploration, development and production functions with distribution activities. Traditional approaches to rate-making are essentially incompatible with commercial risk ventures, because they preclude the upside prospect of high returns which commercial venturers normally require as an incentive for perceived high-risk projects. Financial encouragement of exploration through the rate-making process has traditionally been regarded as both unnecessary and an unwarranted shift of investors' risks to utility ratepayers.

Under existing practice, public utilities must apply for and obtain commission approval for proposed rates. Three calculations are key to setting ut1lity rates: the "rate base," operating expenses, and the allowed "fair rate of return." The rate base is the total amount of capital invested in the utility, net of depreciation. In most states, the rate base includes only plant and equipment in actual service for the utility; it would not include investment in 
exploration or resource development. New facilities are included in the rate base, together with an allowance for interest pald during construction, only after operation has commenced and the plant is "used and useful" in utility operation.

Operating expenses are distinguished from capital items according to Uniform Rules of Account developed for federal and state public utility regulators, and are normally recoverable from utility ratepayers. However, claimed operating expenses, including fuel costs, may be disallowed when they are found to have been Imprudently undertaken, or when they represent payment above fair market value in any dealing between the utility and an affllated corporation such as a resource producer. Given the risks inherent in the resource and the lack of comparable local markets, these standards are difficult to apply in the geothermal context, and necessarily introduce additional uncertainties for the private developer confronting the prospect of regulaton.

The "fair rate of return" for conventional utilities is normally set by the regulatory commission based on a weighted average of the actual interest cost of debt instruments, and the prevailing market rate for equity for companies with similar risk characteristics. Thus, for example, a utility with a high debt-equity ratio will normally be allowed a higher return on equity than one with a more conservative capital structure. Other risk factors--such as the possible obsolescence of a gas plepline, or the relatively high risk borne by a utilty with a heavy capital investment program--may also be taken 
into account under traditional rate-making practices. Even with these kinds of risks factored in, rates of return allowed to conventional utilities typically range from about $10 \%$ to $15 \%$.

Since there are no precise standards for measuring an appropriate rate of return on equity, commissions have some discretion to use rate-of-return adjustments to encourage particular kinds of investment. $^{148}$ However, political pressures and existing utilities' interests tend to constrain the exercise of this discretion. Even if exploration expenses of an integrated development/distribution company were allowed in the rate base, it is unlikely that any commission would allow returns of $30-50 \%$ which private geothermal investors appear to require for investment in high-risk exploration.

148 In a few states, statutes expressly empower the utility commission to authorize an additional rate of return on investments in renewable resources: California allows an additional .5-1\% return, and Washington provides for an additional $2 \%$. 